\title{
How an Irish-American Priest Became Puerto Rican of the Year: Joseph P. Fitzpatrick, S.J., and the Puerto Ricans
}

Claudio M. Burgaleta, S.J.

St. Peter's University, New Jersey

cburgaleta@saintpeters.edu

\begin{abstract}
One of the first and largest migrations of Latin Americans to the United States occurred from Puerto Rico to New York City in the 1950s. At its height in 1953, the Great Puerto Rican Migration saw some seventy-five thousand Puerto Ricans settled in the great metropolis, and by 1960 there were over half a million New Yorkers of Puerto Rican ancestry in the city. The exodus transformed the capital of the world and taxed its social fabric and institutions. Joseph P. Fitzpatrick, S.J. (1913-95), a Harvard-trained sociologist teaching at Fordham University in the Bronx, played a key role in helping both New York City, its people and social institutions, respond with compassion and creativity to this upheaval. This article chronicles Fitzpatrick's involvement with the Puerto Ricans for over three decades as priest, public intellectual, and advocate on behalf of the newcomers, and social researcher.
\end{abstract}

\section{Keywords}

Joseph P. Fitzpatrick - New York City - Catholic sociology - Great Puerto Rican Migration - Puerto Ricans - Puerto Rico - Cardinal Spellman - Ivan Illich

\section{Introduction}

Beginning after World War II and continuing through the 1950s, one of the largest migrations of people occurred from Puerto Rico to New York City, known as the Great Puerto Rican Migration. At its height in 1953, some seventy-five thousand Puerto Ricans settled in the great metropolis, and by 1960 there were

(C) ClAUdio M. BURGALETA, 2019 | DOI:10.1163/22141332-00604006

This is an open access article distributed under the terms of the prevailing CC-BY-NC license at the time of publication. 
over half a million New Yorkers of Puerto Rican ancestry in the city. Joseph P. Fitzpatrick, S.J. (1913-95), ${ }^{1}$ a Harvard-trained sociologist teaching at Fordham University in the Bronx, witnessed this marvel of human transfer made possible by the US citizenship status of the Puerto Ricans, abundant industrial jobs in the North and a weak economy on the island, and cheap air travel between the two points. This article tells the story of how the Great Migration would change his career and personal life for the better, and his pastoral and scholarly contributions to the same had a significant salutary effect on the lives of tens of thousands of Puerto Ricans.

\section{The Beginnings}

Joseph Fitzpatrick's first encounter with living and breathing Puerto Ricans foreshadowed what would become some of the principal aspects of his lifelong relationship with the first large Latin American immigrant group to New York City: priestly ministry and a concern for social justice. It occurred in 1944 while he was serving as a chaplain at a public hospital that catered to the city's poor. He was what Jesuits refer to as a "tertian," or young priest in the final phase of training before taking his final vows in the order, and in his first years after ordination.

In his memoirs, Fitzpatrick recounts encountering a Puerto Rican woman about to give birth by caesarean whom he calls, Mrs. González. ${ }^{2}$ Armed with a vademecum containing basic pastoral phrases in the languages of the poor who were patients in the hospital, he prayed for the woman, administering the sacrament of extreme unction, as it was then called, and comforted her as best he could give his limited Spanish. Later that night, he was called out of his bed to the operating room, to minister to the same woman who was hemorrhaging badly while giving birth to her child. She did not make it, due to a malfunctioning blood-transfusion machine. Sometime later, Fitzpatrick encountered the

1 Joseph P. Fitzpatrick, S.J. was born on February 22, 1913 in Bayonne, NJ. He graduated from St. Peter's Preparatory School of Jersey City, NJ in 1930 and entered the Society of Jesus that same year at the Novitiate of St. Isaac Jogues of the Maryland-New York Province at Wernersville, PA. He studied philosophy and theology at Woodstock College, Maryland, 1934-37 and 194044, respectively. His regency was at Xavier High School, New York City, 1938-40, where he also served as assistant director of the Xavier Labor School. He was ordained on June 24, 1943 at St. Ignatius Loyola Church, New York City and pursued a doctorate in sociology at Harvard University, 1945-48. He died on March 15, 1995 in the Bronx, NY at the age of eighty-two.

2 Joseph P. Fitzpatrick, S.J. The Stranger is Our Own: Reflections on the Journey of Puerto Rican Migrants (Kansas City, MO: Sheed \& Ward, 1996), 4-5. 
head nurse of the maternity department who enlightened him about the full injustice of Mrs. González's untimely death giving birth. It turned out that her caesarean was not necessary, and that it occurred only because the doctor in charge of the delivery insisted with his superiors that it be performed, apparently for the reason that he wanted practice performing the procedure.

This sad episode would be Joe Fitzpatrick's introduction to the often tragic and cruel life of New York's latest immigrant group. It would be several more years before he encountered them again and began to learn about them and the unjust circumstances they found in their new home, as for the next several years he would be living in Boston and pursuing doctoral studies in industrial sociology at Harvard University. Despite his experience with Mrs. González at the public hospital, it would be some time before Fitzpatrick shed his initial impression that the Puerto Ricans were just another immigrant group to New York City, who with the passage of time would assimilate like the Irish, Germans, Eastern Europeans, and Southern Europeans before them. ${ }^{3}$

The metamorphosis in his thinking about the Puerto Ricans began upon his return to New York City in November of 1948, when he began a life-long association with Fordham University as a professor of sociology. During the summers of the mid 1950s, he visited Puerto Rican farm workers near Patchogue on Long Island, while he was serving as chaplain to the Ursuline Sisters. ${ }^{4}$ Early in his Fordham career, Fitzpatrick was asked to be part of a team of researchers producing a study of the Puerto Ricans. Given his background in labor relations, his part of the study focused on Puerto Rican participation in labor unions. In particular, he met and interviewed some Puerto Rican women who were active in the International Ladies' Garment Workers' Union (ILGWU) in 1949. The first-hand meetings with Puerto Ricans that came out of writing that study and the appalling conditions in which they lived and worked, sparked his interest and righteous indignation.

It especially irked him that New York City had encountered all this before with previous waves of immigrants and seemed to have learned nothing about how to welcome these newcomers. Moreover, he was perplexed and ashamed that the sons and daughters of immigrants, Irish, Germans, Eastern and Southern Europeans, were now visiting upon the Puerto Ricans the same prejudice

3 Fitzpatrick, Stranger is Our Own, 3.

4 Joseph P. Fitzpatrick, S.J. to Dr. Terry J. Rosenberg of SUNY Stonybrook, September 10, 1974, Fitzpatrick Papers, Box 9, File 15.

5 Joseph P. Fitzpatrick, S.J. to Patricia Cayo Sexton, February 18, 1983, Fitzpatrick Papers, Box 14, File of 1983 Correspondence. See also Joseph P. Fitzpatrick, S.J. to Dennis Rivera, July 14, 1989, Fitzpatrick Papers, Box 15, File 8. 
and obstacles that their ancestors experienced a century or less before at the hands of white Anglo-Saxon Protestants. He further observed that no one was advocating for the Puerto Ricans. And so was born what would become a lifelong interest in them, both pastoral and scholarly, and advocacy on their behalf that he conceived as twofold: firstly, explaining the Puerto Ricans to New Yorkers (their culture and their experience of New York), as well as New York to Puerto Ricans, and secondly, informing the Catholic Church (bishops, priests, religious, and parishioners) about the religious dimension of the Puerto Rican experience. ${ }^{6}$

Many of Fitzpatrick's efforts to explain the Puerto Ricans to New Yorkers were in the form of talks to run-of-the-mill parish gatherings and organizations, such as Communion breakfasts and meetings of local councils of the Knights of Columbus. He was a gifted speaker and the timeliness of the topic, made him an attractive draw for many of these groups. ${ }^{7}$ Fred Jackman, the president of one such Catholic organization, the Stella Maris Club of St. Mary's Roman Catholic Church of Flushing, N.Y., observed in early 1954: "I personally have never heard you [Fitzpatrick] speak but have heard countless number of people comment favorably on your talks including many persons who have had prejudices against the Puerto Rican people."8 Perhaps the most famous of these talks, which generated much publicity and controversy for him and the situation of the Puerto Rican newcomers, was delivered on the occasion of the golden jubilee of the Vera Cruz chapter of the Knights of Columbus in the Bronx on May 18, 1952.9

Fitzpatrick's talk that evening made the case to the predominantly Irish and Italian American audience that the Puerto Rican migration to New York that was then in full swing, was very similar to that of their immigrant ancestors. He begged the Knights not to let history repeat itself with the Puerto Ricans and pointed out the responsibility that they had as members of a Catholic

6 Fitzpatrick, Stranger is Our Own, 8.

7 See Edward F. Murphy, Jr. of the Holy Name Society of St. Brendan's Church, Bronx, N.Y. to Joseph P. Fitzpatrick, S.J., December 24, 1953, Fitzpatrick Papers, Box 12, File 34. See John T. Collins to Charles Ridder, April 13, 1954, Fitzpatrick Papers, Box 12, File 34 extolling Fitzpatrick's talk on the Puerto Ricans to the Communion Breakfast of the Catholic Institute of the Food Industry. See Juliana Rasic of the Riverdale Country School for Girls to Joseph P. Fitzpatrick, S.J., December 8, 1958, and Francis McDermott, secretary of the Holy Name Society of St. Thomas Aquinas Church, Bronx, N.Y., to Joseph P. Fitzpatrick, S.J., November 26, 1959, both in Fitzpatrick Papers, Box 13, File 7.

8 Fred Jackman to Joseph P. Fitzpatrick, S.J., undated, Fitzpatrick Papers, Box 13, File 16.

9 Joseph P. Fitzpatrick, S.J. "Puerto Ricans in New York: The Great Challenge to the Charity of Catholics," in Fitzpatrick, Stranger is Our Own, 97-102. 
organization with roots in Spain to the newcomers who shared that heritage and the Catholic faith. ${ }^{10}$

The most fierce critiques of the talk came in the wake of Arthur Mulligan's article in The Daily News (August 17, 1952).. ${ }^{11}$ It would not be the last time Fitzpatrick would be criticized for his advocacy of the Puerto Ricans, and receive letters, such as this anonymous one mocking him for what the author perceived to be his naive defense of the Puerto Ricans: "Please for the sake of knowing take off your collar take an apartment or a room amongst these people and see for yourself. One doesn't see much living on a college campus and preaching from an altar. Since you're a priest you may not be allowed to speak freely then at least be quiet." 12

In the summer of $195^{2}$ (part of June and July), Fitzpatrick made the first of numerous visits to Puerto Rico over the next decades of his life. Writing to John J. Kane of the Sociology Department of the University of Notre Dame, he described both his initial impression of the island and the pastoral reason that had brought him there. He wrote: "The Island has a thousand marvels and a thousand mysteries. But the N.Y. situation is sad and getting sadder. Say a prayer that we'll get on the ball - and fast. Otherwise it will be tragic. It almost already is."13 During the month's stay, which was arranged by an American businessman in Puerto Rico, Frank Goering, who had been present at Fitzpatrick's speech to the Knights of Columbus a month earlier, Fr. Joe sought to raise scholarship money for Puerto Ricans in the States. ${ }^{14}$ However, the whirlwind trip proved to be more than that as he met with civil and religious leaders on the island including James Davis, the archbishop of San Juan (in office 1943-64). ${ }^{15}$

Upon returning from the visit, Fitzpatrick wrote a report that underscored two realities that would come to occupy much of his time in the years to come. He noted the need to develop better communications between Puerto Rico and the mainland so as to support the newcomers who were arriving. And secondly, he was shocked by the little contact that existed between the leadership of the Catholic Church on the island and those involved in the economic development of Puerto Rico, and recommended that this state of affairs be

$10 \quad$ Fitzpatrick, Stranger is Our Own, 100-1.

11 Fitzpatrick, Stranger is Our Own, 12-13.

12 Anonymous letter to Joseph P. Fitzpatrick, S.J., June 24, 1957?, Fitzpatrick Papers, Box 12, File 29. See also letter from a "Civic Minded Group" to Joseph P. Fitzpatrick, S.J., May 1, 1958, Fitzpatrick Papers, Box 12, File 30.

13 Joseph P. Fitzpatrick, S.J. to John J. Kane, August 5, 1952, Fitzpatrick Papers, Box 13, File 15.

14 Joseph P. Fitzpatrick, S.J. to Frank Gehring, February 25, 1952, Fitzpatrick Papers, Box 13, File 14. In his memoirs, Fitzpatrick spells the name as Goering and not as Gehring.

15 Fitzpatrick, Stranger is Our Own, 14. 
changed. ${ }^{16}$ It would not be until May 1953 that the first of these concerns would begin to be addressed in an efficacious manner.

\section{$3 \quad$ Cardinal Spellman and Ivan Illich}

On May 10, 1953, Fitzpatrick addressed the World Sodality Day at Edward's Parade, Fordham University in the Bronx. The sodality was a world-wide religious organization of Catholic college students devoted to Mary. In 1953, the event was held at Fordham University and as usually happened, the archbishop of New York, Francis Cardinal Spellman (1889-1967), was in attendance. Amidst unusually hot temperatures that caused many of the attendees to faint, Fitzpatrick delivered the sermon: "A Plea for Christian Unity." In it, he spoke about the situation of Puerto Rican Catholics in New York and the challenge it posed to the church. ${ }^{17}$

Fitzpatrick's words raised the curiosity of Cardinal Spellman, who shortly after that sermon heard similar concerns expressed by one of his own diocesan priests. Spellman summoned Fitzpatrick and about twenty others concerned with the Puerto Ricans to his office, and inquired about what he was doing right and wrong in the pastoral care of the new migrants. ${ }^{18}$ Spellman's behavior at the meeting impressed Fitzpatrick, and his actions on behalf of Puerto Ricans following the meeting earned the Jesuit's gratitude and admiration for years to come, even when Spellman would come under criticism for his support of the Vietnam War, even while Fitzpatrick opposed it. ${ }^{19}$ A friendship developed between the two, born of mutual respect and solidarity in the cause of welcoming and ministering to the Puerto Rican newcomers. Spellman sought Fitzpatrick out for advice, and Fitzpatrick would turn to the cardinal for support when he was criticized for his advocacy work on behalf of the Puerto Ricans. $^{20}$

Also in the Spring of 1953, Fitzpatrick met for the first time another ally in his work with the Puerto Ricans, and a friend for life. Fr. Ivan Illich (1926-2002)

16 Fitzpatrick, Stranger is Our Own.

17 Fitzpatrick, Stranger is Our Own, 14-15.

18 Fitzpatrick, Stranger is Our Own, 15.

19 Fitzpatrick, "New York City and Its Puerto Rican 'Problem,"” in Fitzpatrick, Stranger is Our Own, 162. See also Joseph P. Fitzpatrick, S.J. to Francis Cardinal Spellman, August 15, 1959, Fitzpatrick Papers, Box 13, File 1.

20 See Joseph P. Fitzpatrick, S.J. to Francis Cardinal Spellman, October 17, 1959, Fitzpatrick Papers, Box 13, File 1 and Francis Cardinal Spellman to Joseph P. Fitzpatrick, S.J., October 20, 1959, Fitzpatrick Papers, Box 13, File 1. 
was an intense, Semitic-looking, Austrian-born intellectual of ethnic Croatian descent, who had studied natural sciences in Florence, philosophy and theology in Rome, and earned a doctorate in history at Salzburg. He made his way to New York and had been assigned by Cardinal Spellman to Incarnation Parish in Upper Manhattan. The parish was quickly becoming Puerto Rican, and Illich became interested in their plight.

Part of Illich's outreach to Puerto Ricans in a culturally-sensitive or inculturated way in which Fitzpatrick collaborated directly involved the San Juan Fiesta. The fiesta had begun in 1953 at the request of Cardinal Spellman, and for the next two years had been held indoors at St. Patrick's Cathedral in Midtown Manhattan. Illich argued that such an arrangement lacked the flavor of fiestas on the island, which were outdoor affairs, combining civic and religious celebrations. With Fitzpatrick's help, he convinced Msgr. Joseph F. Connolly (1909-73), who organized the affair, and Fordham University to hold the event outdoors on the Bronx campus in June of 1956. It involved an outdoor religious procession from one end of the eighty-five-acre campus to the other, where Cardinal Spellman celebrated Mass and delivered a Spanish-language sermon. And although only a few thousand were expected, at the end of the day over thirty thousand participated. ${ }^{21}$ Fitzpatrick remained faithful to the event, and while the fiesta would diminish in popularity over time, at its twenty-fifth anniversary in 1979, the organizing committee named him "The Puerto Rican Man of the Year."22

Another successful project that Fitzpatrick undertook in collaboration with Illich and with Spellman's financial support and blessing was "The First Conference on the Spiritual Care of Puerto Rican Migrants," held in San Juan and Ponce on April 11-16, 1955. It brought seasoned priests from the island in contact with mainland priests who were interested in ministering to the newcomers. Key to the organization of the conference was the pastoral work of Father Thomas Gildea, C.SS.R., who had set up Ayuda Católica, an organization that made contact with Puerto Rican migrants at the San Juan Airport, found out where they were headed in the States, and sought to inform the parishes where they were to take up residence on their arrival. In this way, the local parish priests would know of the newcomers' presence and, in theory, reach out to them in assistance. ${ }^{23}$

21 Fitzpatrick, Stranger is Our Own, 19. See also Joseph P. Fitzpatrick, S.J. to Roy Rozenzweig, November 26, 1990, Fitzpatrick Papers, Box 15, File 12.

22 Fitzpatrick, Stranger is Our Own, 20.

23 Fitzpatrick, Stranger is Our Own, 21. 
The 1955 conference also facilitated the establishment of the Institute of Intercultural Communication (ICC) at the Catholic University of Puerto Rico in Ponce, the island's second largest city. The institute would become an important training center for church workers working with the Puerto Rican diaspora in the States. The rector of the university, Father William Ferree, S.M. $\left(1905^{-85}\right)$, who was present at the conference, was impressed with Illich and found in him a kindred spirit concerned with social action and the plight of Puerto Rican migrants. Ferree suggested to the chancellor of the university, Bishop James Edward McManus of Ponce (in office 1947-63), that he prevail on Cardinal Spellman to assign Illich to the university as vice rector. ${ }^{24}$

Illich's arrival in Ponce in the Fall of 1956 would lead to what may arguably be called the most important collaboration between himself, Fitzpatrick, and Spellman. Once again with Spellman's financial and moral support, Illich founded the ICC in 1957. The pastoral workers who took part in the six-week summer training program at the ICC studied Spanish intensively, as well as Puerto Rican culture and the problems associated with migration to the States. On Tuesdays, Wednesdays, and Thursdays from seven to nine in the evening Fitzpatrick took charge of them and lectured on Puerto Rican culture and migration matters, inviting outside speakers from the island to address different aspects of Puerto Rican social, political, and religious life. ${ }^{25}$ Sometimes, the speakers who were invited to lecture were quite prominent, for example Doña Felisa Rincón de Gautier (1897-1994), the mayor of San Juan. ${ }^{26}$

After the intensive six-week program at the university, the priests spent another month living and working in a Puerto Rican parish, while those who were not ordained traveled around the island to become more familiar with its people. In addition to the program on the island during the summers, a satellite center was set up in a Catholic high school in New York City where those who could not make it down to Ponce could avail themselves of mini-courses on language and culture taught on Saturday mornings. The ICC continued for another fifteen years, until it ceased operations in 1972. Fitzpatrick would be a faithful faculty member during all those years, even after Illich left as the institute's director in 1960 because of a conflict with the bishop of Ponce. ${ }^{27}$

Another long-lasting institutional and personal association that developed from his visits to Ponce was his friendship with Sister Isolina Ferré Aguayo

\footnotetext{
24 Fitzpatrick, Stranger is Our Own, 22-23.

25 Fitzpatrick, Stranger is Our Own.

26 Joseph P. Fitzpatrick, S.J. to Doña Felisa Rincón de Gautier, July 11, 1957, Fitzpatrick Papers, Box 12, File 29.

27 Fitzpatrick, Stranger is Our Own, 29.
} 
(1914-200o), and the community outreach center that she founded with the help of her family and now bears her name, the Centro Sor Isolina Ferré, located in the La Playa section of the city. Sister Isolina, sometimes called "the Puerto Rican Mother Teresa," was a member of the Missionary Servants of the Blessed Trinity, the female branch of the religious community to which Fitzpatrick's brother, Vincent (1915-2006), belonged. She was also a member of one of Puerto Rico's most distinguished and well-to-do families, with roots in Ponce. Her brother, Luis Ferré, would be the island's governor from 1968 to $1972 .{ }^{28}$

Fitzpatrick's interest in the Puerto Ricans, both on the island and in New York City, continued to grow throughout the 1950s. He settled into a pattern of summer visits to the island to teach at the ICC that lasted through 1971, which also allowed him to visit other parts of Latin America and the Caribbean, before returning to the New York. And of course, his friendship and involvement with the ministry of Sister Isolina and her centers brought him to Puerto Rico at other times during the year on a regular basis. All this contributed to a firsthand knowledge of Puerto Rican culture and the challenges it faced, on and off the island, which transformed his public persona with regard to the Puerto Ricans. As the 1950s progressed, Fitzpatrick transformed from a concerned priest and sociologist of the Puerto Rican migration, to a public intellectual and advocate who spoke from experience and authority about a wide-ranging spectrum of issues associated with the Puerto Ricans, on and off the island. ${ }^{29}$

28 Fitzpatrick, The Stranger is Our Own, 38-39. For a biography of Sor Isolina, see Carmen Dolores Hernández, En busca de Isolina (Guaynablo, Puerto Rico: Editorial Plaza Mayor, 2014).

29 His correspondence includes numerous invitations from diverse professional and Catholic groups requesting that he come and speak to them about the Puerto Ricans and Catholic social teaching. For example, see invitations from $1960-61$ to speak to Jesuit tertians at Pomfret, CT, give the community retreat to Jesuit theologians at Woodstock, Maryland, address the Jesuit novices and juniors at Wernersville, PA, speak to the staff of the New York Foundling Hospital, speak to the nurses in training at St. Vincent Hospital, New York City, speak to cadets at the New York City Police Academy, speak to the faculty of Theodore Roosevelt High School, Bronx, N.Y., speak to the seminarians of St. Bernard Seminary, Rochester, N.Y., address the St. Thomas More Legal Society of New York University, speak to the St. Apollonia Guild of Catholic Dentists of New York City, address sisters in formation at Maryknoll, N.Y., address policemen at a conference sponsored by 
Fitzpatrick's advocacy began at home, as it were. His passion for the cause of the Puerto Ricans led him to intervene on their behalf with fellow Jesuits. At times, his efforts seem naive and verging in what Jesuits call, interfering in the office of another or more prosaically, butting-in. For example, in June of 1957, he heard that a brother Jesuit, Father E. L. Colman was giving retreats to priests of the archdiocese of New York at St. Joseph's Seminary in Yonkers. He wrote Fr. Colman and encouraged him to speak to the priests about ministry to the Puerto Ricans since in some parishes in the archdiocese pastors were resisting welcoming the newcomers. With the suggestion, he enclosed articles and statistics that could be used to make the case. Yet he concluded, as if aware that he had crossed a line that he should not have, with the disclaimer: "If, in your better judgment, you think you shouldn't mention it, by all means discard the whole idea. If I have been too bold in mentioning this, I hope you will pardon me."30

More typically, however, Fitzpatrick's advocacy for the Puerto Ricans among the Jesuits took the less intrusive form of explaining why a suggested course of action should be followed. By the late 1950s, Fitzpatrick was seen by fellow Jesuits as the go-to-man for not only questions about sociology, ${ }^{31}$ but for all things having to do with the Puerto Ricans. ${ }^{32}$ His correspondence is filled with requests from Spanish Jesuits seeking help in finding a Puerto Rican parish in New York where they may work, often while studying, such as this one from Francisco Alcina, a Spanish Jesuit missioned to Japan: "I wrote a friend of mine in Woodstock [College, a Jesuit seminary in Maryland] asking for help.

the Manhattan-Westchester Region of the National Conference of Christian and Jews, lecture to the Eugene Victor Debs Society of Brooklyn College, Annual Alumni Dinner of Casita María and Carver Community Center in East Harlem, give a course to the employees of the Department of Health of Catholic Charities of the archdiocese of New York, Fitzpatrick Papers, Box 13, Files 6 and 7.

30 Joseph P. Fitzpatrick, S.J. to E. L. Colman, S.J., June 17, 1957, Fitzpatrick Papers, Box 12, File 31.

31 Francisco Ivern, S.J. to Joseph P. Fitzpatrick, S.J., April 21, 1960, Fitzpatrick Papers, Box 13, File 3 .

32 Stephen L. Hagarty, S.J. to Joseph P. Fitzpatrick, S.J., March 25, 196o, and A. D. Spearman, S.J. to Joseph P. Fitzpatrick, October 28, 1959, both in Fitzpatrick Papers, Box 13, File 3. See letter of John J. McGinty, S.J., Provincial of the New York Province of the Society of Jesus, to Joseph P. Fitzpatrick, S.J., August 25, 1961, Joseph P. Fitzpatrick, S.J. Personnel File, New York Province of the Society of Jesus Archives, Provincial's Office, 39 East 83rd Street, New York, NY, asking advice on opening a Jesuit house at the University of Puerto Rico that would serve as a campus ministry center and magazine. 
His answer was: Why don't you write to 'the Apostle of the Puerto Ricans' Rev. Fr. Joseph Fitzpatrick, S.J." ${ }^{33}$

His earliest publication explaining the Puerto Rican migration to an educated audience appeared in July, 1955, when at the behest of Dorothy Dohen, the editor of Integrity, he published "Catholic Responsibilities and New York's Puerto Ricans."34 Integrity, a popular Catholic magazine aimed at educated Catholics committed to what was called at that time "the Lay Apostolate," or the service of God through the service of the world as Catholic lay people who were neither priests, sisters, or brothers. While such an ideal of service and seeking out holiness as a lay person working in the world would be proposed to all the baptized in the teachings of the Second Vatican Council (1962-65), in the 1950s, this was still an elite vanguard movement in the church. Dorothy Dohen (1924-84), whom Ivan Illich introduced to Joe Fitzpatrick, would become a close friend, student, and colleague in the Fordham Sociology and Anthropology Department. ${ }^{35}$

Over time, Fitzpatrick would publish dozens of articles in other popular Catholic publications such as America, Commonweal, and Catholic Mind, often reworked addresses that he had given, in his crusade to dispel myths about the negative social effects of the Puerto Rican migration. As we have seen above, those efforts often earned him blistering critiques from his audience or those who heard about his speeches and writings. ${ }^{36}$ Fitzpatrick remained optimistic about the blessings that the Puerto Rican migration brought to New York City. He wrote to the editor of Harper's Magazine, John Fischer, who did not share that optimism, ${ }^{37}$ and remarked that "people have been raising the same lament for the last hundred and fifty years. It may seem like a strange contradiction that I find in the pessimism of the past one good reason for hope for the present. But I do think the optimism makes sense." ${ }^{38}$ By 1960, he takes

33 Francisco Alcina, S.J. to Joseph P. Fitzpatrick, S.J., April 28, 1957, Fitzpatrick Papers, Box 12, File 28 .

34 Fitzpatrick, "Catholic Responsibilities and New York's Puerto Ricans," in Fitzpatrick, Stranger is Our Own, 107-14.

35 Fitzpatrick, Strange is Our Own, 22.

$3^{6}$ See Bud Talbot, S.J. to Joseph P. Fitzpatrick, S.J., January 8, 196o, Joseph P. Fitzpatrick, S.J. to Rita Long, January 8, 1960, Joseph P. Fitzpatrick, S.J. to Catherine Kilbridge, November 30, 1959, Joseph P. Fitzpatrick, S.J. to Edward Lavin, S.J., November 7, 1959, all in the Fitzpatrick Papers, Box 13, File 1.

37 See John Fischer, editor of Harper's Magazine, to Joseph P. Fitzpatrick, S.J., January 20, 1960, Fitzpatrick Papers, Box 13, File 1.

38 Joseph P. Fitzpatrick, S.J. to John Fischer, January 13, 196o, Firtzpatrick Papers, Box 13, File 1. 
these criticisms in stride, less focused on the "enmity," as he called it, that they produced and more hopeful about the good that his public interventions on behalf of the Puerto Ricans may accomplish. ${ }^{39}$

Fitzpatrick's first experience of advocacy for the Puerto Ricans outside of Catholic circles came in 1953. He was invited to participate on an advisory panel of a Board of Education study funded by the Ford Foundation of the education of Puerto Ricans in New York City called The Puerto Rican Study, 1953-1957: A Report on the Education and Adjustment of Puerto Rican Pupils in the Public Schools of the City of New York. ${ }^{40}$ Over the course of study's duration many experiments were tried to determine which types of learning experiences would be most helpful to Puerto Rican children. Materials were generated for the use of public-school teachers and recommendations made to improve instruction in the New York public schools for the Puerto Ricans, many of which continued to be repeated in subsequent studies.

But it was not only to non-Puerto Ricans that Fitzpatrick would seek to explain what was happening to the Puerto Ricans who kept coming to the States. A concern of his was to explain the United States to the Puerto Rican migrants, as well as how migration was changing and challenging many of the values and traditions they held dear from the old country. One such address was given on the occasion of the installation of new officers to the Consejo de Organizaciones Puertorriqueñas e Hispano-Americanas de Nueva York on January 21, 1961. He underscored one of the basic principles that he had ascertained from working and studying the Puerto Rican migration: "One integrates from a position of strength, never from a position of weakness." 41

\section{$5 \quad$ Researching the Puerto Rican Migration}

A unique aspect of Fitzpatrick's involvement with Puerto Ricans is that he did so not only as concerned priest, public intellectual, and advocate, but also as professional sociologist. While trained at Harvard as an industrial sociologist who at the beginning of his teaching career at Fordham focused on the sociology of labor relations, by the mid 1950s, his interests in the Puerto Rican migration also began to dominate his research and academic writing. He used the summer months he spent on the island teaching at the ICC for over a decade

\footnotetext{
39 Joseph P. Fitzpatrick, S.J. to Walter [Janer, S.J.?], February 29, 1960, Fitzpatrick Papers, Box 13, File 1.

$40 \quad$ Puerto Rican Study.

41 Puerto Rican Study, 33.
} 
and a half absorbing Borinquen language and culture, as well as conducting research for future publications. ${ }^{42}$ The first of his academic publications about the Puerto Ricans was published in Fordham University's Thought: A Review of Culture and Ideas, a quarterly peer-reviewed journal that specialized in lengthy articles on a variety of topics in the humanities from a Catholic perspective, in 1955 at the request of its editor.

"The Integration of Puerto Ricans" 43 is a sociological analysis of the Puerto Rican migration and its integration into American society, focusing on the challenges to that integration. He argued that it was from a position of strength that newcomers best integrated into the dominant society, and this meant vibrant neighborhoods with effective religious, social, and civic organizations and structures, such as churches, families, cultural, athletic, and political clubs, etc. However, he cautioned that many progressive elements in American society such as non-segregated public housing, the integrated parish rather than the national parish, public social services, rather than the assistance provided by immigrant mutual assistance societies and the patronage of political machines, threatened the integration of the Puerto Rican migrants.

In the 1950s United States, during the first decade of the Cold War and where the public ethos was integration into the dominant culture and the downplaying of ethnic and racial differences, Fitzpatrick's was a dissonant perspective. He himself recognized that the ideas that he proposed in the article "became an important theoretical basis for my book, Puerto Rican Americans. It was my first serious sociological article about migration and brought me to the attention of my sociological colleagues throughout the country as an important scholar in the field of inter-ethnic and minority relations." ${ }^{44}$ Here was Fitzpatrick the professional social scientist looking at the Puerto Rican migration from a more detached professional perspective than his impassioned writing and speech-making for more popular audiences. Missing was his rousing rhetoric of advocacy to do something for the Puerto Ricans, even if in this more neutral scholarly voice he continued to raise questions of concern about the social trends he identified in the article. ${ }^{45}$

Fitzpatrick's scholarly output for the next several decades would be devoted to answering these questions. During the 196os, his scholarly research would

Joseph P. Fitzpatrick, S.J. to Frank Santopolo, July 28, 1958, Fitzpatrick Papers, Box 12, File 26. Joseph P. Fitzpatrick, S.J. to John Martin, July 11, 1959, Fitzpatrick Papers, Box 13, File 2.

43 Fitzpatrick, "The Integration of the Puerto Ricans," in Fitzpatrick, Stranger is Our Own, $115^{-22 .}$

44 Fitzpatrick, Stranger is Our Own, 24.

45 Fitzpatrick, "The Integration of the Puerto Ricans," 120. 
turn in particular to the issue of juvenile delinquency, a plague that much affected the Puerto Rican community in New York at that time. And as if to inaugurate this avenue of research, the summer of 1959 saw Fitzpatrick much concerned and embroiled in a gang-related crime wave in the city. One case in particular unleashed a wave of anti-Puerto Rican sentiment and vitriol in the press and in society at large: the case of "Dracula and the Umbrella Man." It seems to mimic the popular culture of the time and Broadway's hit of the moment, West Side Story. ${ }^{4}$

Fitzpatrick came to the defense of the Puerto Ricans at a time when few were speaking on their behalf. And he considered it "the most important thing I have ever done [...]. And what pleased me the most was the fact that the great public defense of them [the Puerto Ricans] came from the Church and from a Priest." ${ }^{\prime 7}$ He delivered a public lecture on October 8, 1959 at the Fordham Business School entitled "Delinquency and the Puerto Ricans." ${ }^{38}$ Well attended and covered by the press, it became a sensation, earning Fitzpatrick a story and picture in Time magazine. El Diario's coverage, the Puerto Rican daily of New York, turned him into the hero of the Puerto Rican community, yet again.

The research on delinquency led Fitzpatrick to focus on a related plague in the Puerto Rican community, drug abuse, and rehabilitation programs to combat it. Already widespread in the community in the 1950s, Fitzpatrick's first encounter with this blight was through the efforts of the Rev. Norman Eddy (1920-2013), a Protestant pastor in East Harlem. He recalled the Rev. Eddy as "a very spiritual man of great compassion, but with a great deal of common sense," 49 who worked with the local gangs. Eventually Eddy focused on preventing drug abuse and his parish became one of the more effective centers in the city. His approach was faith-based, but not proselytizing, rather "an effort to bring the youths to a deeper sense of self-respect and self-dignity and move them along to a productive adulthood."50

In the second half of the 196os, Fitzpatrick, along with his Sociology colleagues at Fordham, was asked by the federal government to undertake an evaluation of drug rehabilitation programs in New York City started by Puerto Rican psychiatrist Efrén Ramírez. Ramírez had been invited to New York by

\footnotetext{
46 Fitzpatrick, Stranger is Our Own, 40-41.

47 Joseph P. Fitzpatrick, S.J. to Frank and Mary Santopolo, December 26, 196o, Fitzpatrick Papers, Box 12, File 15.

48 The talk was eventually published by Catholic Mind as "New York City and Its Puerto Rican 'Problem," in Fitzpatrick, Stranger is Our Own, 151-63.

49 Stranger is Our Own, 45.

5o Stranger is Our Own.
} 
Mayor John Lindsay (in office 1966-73) to replicate the success he had in rehabilitating addicts in Puerto Rico. Convinced that drug addiction was a selfdestructive evasion of reality, he employed a confrontational approach in a group setting to compel his clients to break down, admit their powerlessness, and face their reality and that of the world around them. The Fordham study of this program that Fitzpatrick did for the federal government challenged Ramírez's claims of success and found that many Puerto Ricans left the program. It was too much of a humiliating experience for the addicts. ${ }^{51}$

On the other hand, the study identified other programs and approaches that were more successful. One such program was SERA, which was started by a reformed Puerto Rican addict from the Bronx. Its approach was especially tailored to the Puerto Ricans and was community-centered, bilingual, and less confrontational. Eventually, the SERA program was discontinued due to the recidivism of its leadership and financial improprieties. Another similar program was PROMESA, started by Manuel Díaz and then developed into one of the largest rehabilitation programs in the city by Félix Velásquez. ${ }^{52}$

Yet, undeterred by the dismal landscape of the drug abuse plague on the Puerto Rican community, Fitzpatrick continued to study the problem and suggest solutions throughout the 1970s. From 1975 through 1977, he undertook a major study of Puerto Rican addicts with other colleagues from Fordham called "Puerto Rican Addicts and Non-Addicts: A Comparison." Along with Drs. John M. Martin, James Brown, and Morton Levine, he studied fifty Puerto Rican male addicts and non-addicts in the East Tremont section of the Bronx, just south of the university. The goal of this study was to consider drug addiction as a neighborhood problem and examine it in its community setting and how the community dealt with it. ${ }^{53}$

Without question the most important scholarly contribution that Father Fitzpatrick made to the study of the Puerto Rican migration was his book Puerto Rican Americans: The Meaning of Migration to the Mainland. First published in $1971,{ }^{54}$ and then reissued in a revised edition in $1987,{ }^{55}$ the work occupied Fitzpatrick in the late 196os and was the fruit of almost two decades of working on behalf of, studying, and falling in love with the Puerto Rican people on

\footnotetext{
$5^{1} \quad$ Fitzpatrick, Stranger is Our Own, 45-46.

$5^{2}$ Fitzpatrick, Stranger is Our Own, 46.

53 Fitzpatrick, Stranger is Our Own, 46.

54 Fitzpatrick, Puerto Rican Americans: The Meaning of Migration to the Mainland (Englewood Cliffs, NJ: Prentice-Hall, Inc., 1971).

55 Fitzpatrick, Puerto Rican Americans: The Meaning of Migration to the Mainland, 2nd ed. (Englewood Cliffs, NJ: Prentice-Hall, Inc., 1987).
} 
the island and in the diaspora. The work focused on the Puerto Ricans' struggle to retain their identity on the mainland by presenting historical, cultural, and socio-economic data about the island and the migration to the continental United States. Several chapters dealt with specific areas of the Puerto Rican experience in the schools of New York City, the social-welfare system of the United States, and incidences of mental illness and drug addiction among those who migrated. Perhaps its most important contribution, and this was Fitzpatrick's own opinion, were the chapters that presented Puerto Rican culture, religion, and society. ${ }^{56}$

The student and ethnic militancy that gripped the country in the 196os and 1970 s also affected the Puerto Rican community, and Fitzpatrick was wary of it. He was not unsympathetic to many demands made by Fordham University students at this time. Indeed, he played a key mediation role between the Fordham student protestors and the university administration. As explained elsewhere below, he supported ASPIRA's change of mission in the late 1960s when it moved beyond its original mission of locating promising Puerto Rican students and supporting them economically and academically and embraced direct community action and protest for social change. And encouraged its leadership to follow the example of Mexican American activist in this regard. ${ }^{57}$ However, he cautioned Dr. Paul J. Reiss, the vice president of academic affairs of Fordham University (1963-85), who was interested in organizing a summer institute on "The Puerto Rican in College," about a disastrous experience he had at Princeton University in November 1971. At a similar event, militant students took over the event, dismissed its director and all non-Puerto Rican administrators from the hall, and ran the affair according to their own design. ${ }^{58}$

During the 1970s, Fitzpatrick writes in his memoirs that a number of Puerto Rican social scientists began to appear on the professional scene who challenged his writings on the Puerto Ricans as assimilationist. ${ }^{59}$ While he defended himself from these charges in writing, there is no more eloquent rebuttal to them than Fitzpatrick's life work on behalf of many Puerto Rican organizations who

\footnotetext{
56 Fitzpatrick, Stranger is Our Own, 64-65.

57 Joseph P. Fitzpatrick, S.J. to Louis Nuñez, n.d., 1968, Fitzpatrick Papers, Box 10, File 47.

$5^{8}$ Joseph P. Fitzpatrick, S.J. to Paul J. Reiss, September 25, 1972, Fitzpatrick Papers, Box 9, File 12.

59 Fitzpatrick, Stranger is Our Own, 68.
} 
sought both to help Puerto Ricans at risk, as well as promote Puerto Rican flourishing in various ways, from the legal and educational fields to the arts and culture. It was a concern of Fitzpatrick's from the mid 196os that Puerto Rican Catholics in New York were not more involved in civic organizations, and if they were that, they were too intolerant of other Puerto Rican Catholics who did not belong to the same religious organizations as they did. As he put it to a friend: "One does not have to be a Cursillista to be a good Catholic." ${ }^{\prime 0}$ To remedy the situation, Fitzpatrick himself participated, as we shall see below, in many Puerto Rican civic organizations that were not Catholic or who were comprised of Puerto Ricans who were not practicing Catholics.

Several of these organizations would honor him with awards for his support and service, including the 1967 "Operation Friend Award" of Radio Station $\mathrm{WBNX}^{6}{ }^{61}$ for promoting better understanding between the New York City Police Department and the Spanish-speaking community, the 1983 "Special Award for Service to the Puerto Rican Community" of the Puerto Rican Family Institute, ${ }^{62}$ the 1986 "Special Award" of the Puerto Rico Chamber of Commerce of New York, ${ }^{63}$ and the 1987 "Special Award for Service to the Puerto Rican Community" of the Puerto Rican Bar Association. ${ }^{64}$ In this section, I would like to highlight Fitzpatrick's involvement with some of them.

Educational achievement has long been a challenge for the Puerto Rican migration, and it did not escape Fitzpatrick's attention. From the mid 1950s on, he participated in various study groups and conferences that dealt with the education of the Puerto Rican child. ${ }^{65}$ He consistently underscored the importance of fostering Puerto Rican identity, and language maintenance or

6o Joseph P. Fitzpatrick, S.J. to Chacón, February 28, 1965, Fitzpatrick Papers, Box 10, File 5. Original letter in Spanish.

61 Fitzpatrick, Stranger is Our Own, 218.

62 Fitzpatrick, Stranger is Our Own, 220.

63 Fitzpatrick, Stranger is Our Own.

64 Fitzpatrick, Stranger is Our Own.

65 See Puerto Rican Study; "The Changing Neighborhood and the Parochial School," address to the Committee for the Spanish-Speaking of Chicago, November 1, 1956, in Fitzpatrick, Stranger is Our Own, 133-40; "The Catholic School: Its Place in the Witness of the Church," paper delivered at workshop on inner-city schools sponsored by the superintendent of schools, Archdiocese of New York, November 11, 1965, in Fitzpatrick, Stranger is Our Own, 179-87; "The Role of Language as a Factor of Strength for the Puerto Rican Community," paper delivered at "The Puerto Rican Child and His Cultural Context," a conference held at Barranquitas, Puerto Rico, November 18-20, 1965, in Fitzpatrick, Stranger is Our Own, $164-73$. 
bilingual education as a part of this, as an important key for the educational success of the Puerto Rican child.

The first of these that I would like to mention is ASPIRA, a Puerto Rican educational and leadership development organization founded in 1961 by Dr. Antonia Pantoja (1922-2002), ${ }^{66}$ a visionary and dynamic social worker, educator, and community leader that worked with children and adolescents through ASPIRA clubs in schools and high schools. ASPIRA was born out of The Puerto Rican Forum, of which Dr. Pantoja was a founding member in the 1950s. The Forum "prioritized the advancement of their U.S. constituencies and grassroots origins [...] [and] patterned itself after the NAACP and the American Jewish Committee. It aimed for recognition as a broad-based representative of the Puerto Rican community." 67

More successful collaborations between Fitzpatrick and the Puerto Rican educational community occurred in higher education. In the wake of student protests on campuses throughout the country in the late 196os and early 1970s, Latino and African American studies programs and departments were created, which would teach and study these neglected areas in the curriculum, as well as serve as liaisons between the worlds of the academy and these underrepresented communities on campus. Puerto Rican students at the City University of New York and Fordham University were part of this movement. Fitzpatrick's involvement with the Puerto Rican Studies Program at Fordham University is an example of his over forty-year participation in that university's academic life. He also collaborated with the Center of Puerto Rican Studies at Hunter College of the City University of New York (CUNY), as well as Hostos Community College of CUNY, located in the South Bronx and originally established to serve the Puerto Rican community in particular by providing bilingual programs in the health services.

Another major Puerto Rican organization that Fitzpatrick supported was the Puerto Rican Legal and Defense Fund (PRLDEF). The Fund was started in 1972 by a group of three Puerto Rican lawyers, Jorge Batista, Victor Marrero, and César Perales, who sought to replicate the model of the National Association for the Advancement of Colored People (NAACP) and the Mexican American Legal Defense and Education Fund (MALDEF). They desired to provide representation for the Puerto Rican community in class action suits against public

66 Antonia Pantoja, Memoir of a Visionary: Antonia Pantoja (Houston: Arte Publico Press, 2002).

67 Virginia Sánchez Korrol, "The Story of U.S. Puerto Ricans: Part Five, Community and Organization," Centro: Center for Puerto Rican Studies, Hunter College, CUNY; https://centropr.hunter.cuny.edu/education/story-us-puerto-ricans-part-five (accessed July 12, 2019). 
or private agencies that were discriminating against the community. It also had an educational division that worked with Puerto Rican students seeking admission to law school and during their preparation for admission to the Bar. Since 2008, the Fund is known as "LatinoJustice PRLDEF" and its efforts have grown to encompass the defense of the civil rights of all Latinos and Latinas. ${ }^{68}$ César Perales, the first president of PRLDEF, a Fordham University School of Law alumnus and friend of Father Fitzpatrick's, invited him to join the board of the new organization in March 1973. Fitzpatrick's presence was supposed to bring the board, which was comprised primarily of lawyers, some balance as he was seen as a representative of the broader community.

Fitzpatrick's involvement with organizations that served the Puerto Rican community was not limited to such prominent organizations as the Puerto Rican Family Institute, ASPIRA, PRLDEF, and others that I have examined above. His generosity with his time and talents, especially as a board member, extended to smaller and more local organizations that served specific neighborhoods. For example, Fitzpatrick served on the boards of Group Living in Experience (GLIE), ${ }^{69}$ an organization of small group homes for children in the Bronx, and the Thorpe Family Residence, ${ }^{70}$ which operates two residences for homeless mothers and children, one transitional and the other permanent, also in the Bronx..$^{71}$

In 1969, in collaboration with colleagues from Fordham University, he started a delinquency prevention program that was community based in the East Tremont section of the South Bronx called The Neighborhood Youth Diversion Program. ${ }^{72}$ As we have seen above, this was a neighborhood that Fitzpatrick would become very familiar with from his $1975^{-77}$ research on addicts and non-addicts from the area. Fitzpatrick was a founder of the center in 1969 and would serve on its board until his death. ${ }^{73}$

\section{$7 \quad$ Boricua Friends in High Places and at the Grassroots}

I turn now to the many friendships that Fitzpatrick developed in the community among both men and women of learning, influence and power, as well

\footnotetext{
68 LatinoJustice PRLDEF, http://latinojustice.org (accessed July 9, 2019).

69 Fitzpatrick, Stranger is Our Own, 219.

70 Fitzpatrick, Stranger is Our Own, 220.

71 The Thorpe Family Residences, Inc.; https://catholiccharitiesny.org/our-agencies/thorpefamily-residences (accessed July 12, 2019).

72 Fitzpatrick, Stranger is Our Own, 65-66.

73 Fitzpatrick, Stranger is Our Own, 219.
} 
as at the grassroots with little-known activists and ordinary men and women he encountered in the ordinary course of his life's events. Again, they speak not of someone with an assimilationist agenda, but of friendship grounded in respect, mutuality, and common cause on behalf of Puerto Ricans on and off the island. Friendship for him was a primary category of his spiritual life and sacramental; Fitzpatrick saw God as a friend, saw the friends of God, the saints, as inspiration and guides, and his many friendships with a diverse group of men and women as God's blessings to him.

Earlier in this article, I mentioned two famous Puerto Rican women that were close friends to Fitzpatrick: Sister Isolina Ferré and Dr. Antonia Pantoja. In addition, he mentions in his memoirs several other puertorriqueñas that he met in the 1950s and 196os who instructed him about Puerto Rican culture and inspired him with their dedication to their people. ${ }^{74}$ Luisa Quintero (1903-87) was a columnist for La Prensa and El Diario, Spanish-language dailies of New York, and an activist. Fitzpatrick recalls her omnipresence at major events of the Puerto Rican community in the early years, as well as her political savvy. Matilde Pérez de Silva, who for many years worked at the Office of the Commonwealth of Puerto Rico in New York City and organized trips to Puerto Rico and educational training programs for mainland teachers and social workers working with Puerto Ricans, impressed him with her charm, humor, and gentleness. ${ }^{75}$ Blanca Cedeño (1921-2015) and Marta Valle held important positions in New York City government agencies. These and other women founded the Agrupación Femenina Puertorriqueña and later the Consejo de Organizaciones Puertorriqueñas y Hispano-Americanas de Nueva York, important umbrella organizations of the early days of the Puerto Rican migration.

However, the most influential puertorriqueña in Fitzpatrick's life was Encarnación Padilla de Armas (1909-92). He described her as "my first great teacher about Puerto Rican culture and experience."76 Chacón, as her close friends and Fitzpatrick called her, came from a distinguished family in Puerto Rico. She came to New York in $1945^{77}$ with her son, after her marriage in Cuba ended badly, and met the Spanish journalist Antonio Armas whom she later married. During the 1950s, Encarnación would become the Spanish-language organizer for the Liberal Party, where she excelled as a public speaker, her political acumen, and organizing skills. Fitzpatrick would kid her that she had joined

\footnotetext{
74 Fitzpatrick, Stranger is Our Own, 9-10.

75 Joseph P. Fitzpatrick, S.J., "Homilía del Memorial de Matilde Pérez de Silva," June 30, 1986, Fitzpatrick Papers, Box 34, File 15.

76 Fitzpatrick, Stranger is Our Own, 9.

77 Timothy Matovina, Latino Catholicism: Transformation in America's Largest Church (Princeton: Princeton University Press, 2012), 49.
} 
the wrong party, and that if she were a democrat that she would have quickly achieved elected office. ${ }^{78}$

In addition to the Puerto Rican women who were grassroots community leaders, Fitzpatrick also came to know and befriend a number of prominent Puerto Rican intellectuals in the social sciences. ${ }^{79}$ Two of those were colleagues of his at the Department of Sociology and Anthropology at Fordham, Drs. Lloyd Rogler Canino and Clara Rodríguez. We have already mentioned Dr. Frank Bonilla of the Center for Puerto Rican Studies at Hunter College. Then there is Dr. Anthony Stevens-Arroyo, professor and founding president of the Program for the Analysis of Religion Among Latinos (PARAL) at Brooklyn College, husband of one of Fitzpatrick's doctoral mentees at Fordham, Dr. Ana María Díaz-Stevens, author of a book ${ }^{80}$ analyzing the impact of the early Puerto Rican migration on the archdiocese of New York that grew out of her dissertation work. There are also several other prominent puertorriqueña sociologists that he knew well, including Dr. Marta Tienda of the Office of Population Research of Princeton University and Dr. Virginia Sánchez Korrol of the Department of Puerto Rican and Latino Studies at Brooklyn College and codirector of the Latinas in History Project.

Fitzpatrick also became friends with the brother of his dear friend Sister Isolina Ferré, Governor Luís Alberto Ferré Aguayo (1904-2003). Luís Ferré was the third governor of Puerto Rico from 1969 to 1973 and founder of the New Progressive Party, which favored statehood for the island. Before his election, he was one of Puerto Rico's most prominent industrialists and philanthropists. The family business, Empresas Ferré, began as an iron works to service the island's sugar industry, but Luís diversified and expanded its holdings into cement mills, paper mills, plastics factories, and a trucking company. The Ferré family donated several buildings to the Catholic University of Puerto Rico in Ponce and Luís founded the Ponce Art Museum. Fitzpatrick admired the company's progressive human and labor relations and commented that "everyone singles out Don Luis as the new type of Latin industrial leader, one who has great concern for the community, a sense of social responsibility and who contributes to the welfare of his city and the Island."81 Ferré's philanthrophy

78 Fitzpatrick, Stranger is Our Own, 9-10.

79 Fitzpatrick, Stranger is Our Own, 68-69.

8o See Ana María Díaz-Stevens, Oxcart Catholicism on Fifth Avenue: The Impact of the Puerto Rican Migration upon the Archdiocese of New York (South Bend, IN: University of Notre Dame Press, 1993).

81 Joseph P. Fitzpatrick, S.J. to the Most Rev. Fulton J. Sheen, January 2, 1969, Fitzpatrick Papers, Box 10, File 16. 
also extended to Fitzpatrick and helped him fund a study on the Puerto Rican family in the early $1960 .^{82}$

We mentioned the influential and powerful Puerto Rican friends that Fitzpatrick made throughout his lifetime. But we would be remiss if we did not mention that he had many friendships with those who were less well known. His correspondence is filled with requests from everyday Puerto Ricans whom he met and who write to thank him for his assistance and friendship. Sometimes he provided advice during a family crisis, celebrated the sacraments for them, helped getting a job or getting a child into this or that school or helped getting an apartment in public housing. One such friendship, which he mentions in his memoirs, was with a young man named Frankie Droz, a cafeteriaworker at Fordham University. ${ }^{83}$ Fitzpatrick struck up a conversation with him in the cafeteria and over time a friendship developed. Early on in his encounter with the Puerto Ricans, the Droz friendship provided him with a window into the working-class Puerto Rican family.

He visited Frankie at home in the South Bronx, met his wife and children, and baptized his youngest. Proud of his friendship with Fitzpatrick, Frankie introduced him to his mother who lived nearby in a one-family house that had been converted for multiple dwellers, but with one kitchen and bathroom. Frankie and his mother impressed Fitzpatrick for what he calls their jibaro-identity. The jibaro or jibara was a person from the mountains of Puerto Rico who demonstrated qualities of dignity, honor, trustworthiness, and faithfulness. ${ }^{84}$

\section{8}

\section{Conclusion}

We have seen how Joseph Fitzpatrick, S.J., the freshly-minted Harvard PhD in industrial sociology experienced a life-changing encounter with the Puerto Rican people who migrated to New York in the 1950s, and then with the culture he became acquainted and fell in love with on his many visits to the island. The encounter changed his academic field of study to a new focus on migration and culture, and his friendships with influential personalities in the Catholic Church's response to the Great Migration in New York would make him an important player in their response to the newcomers. From concerned priest for the Puerto Ricans newcomers, he evolved into a student and lover of their

\footnotetext{
82 Joseph P. Fitzpatrick, S.J. to Luís Ferré, May 19, 1961, Fitzpatrick Papers, Box 12, File 9.

83 Fitzpatrick, Stranger is Our Own, 11-12.

84 Fitzpatrick, Stranger is Our Own, 12.
} 
culture and public intellectual who took up their cause against their detractors in the public square.

However, beginning in the 1970s, the changes in and complexity of the Puerto Rican community made it increasingly harder for him to have a handle on and play the same significant role that he played in the community in previous decades. Fitzpatrick recognized this himself, even while he always remained committed to Puerto Rican friends and organizations. Interestingly, he kept a letter that captured this point with poignant irony. It was written by Carmen Canales, secretary of Nativity Parish, then a Jesuit parish on the Lower Eastside with a predominantly Puerto Rican membership, whom Fitzpatrick did not know. And it was sent to him by John F. Talbot, S.J. (in office 1973-78), a friend of Fitzpatrick's and vice-provincial of the Jesuits of New York working in social and pastoral ministries. Talbot had given her Fitzpatrick's book, Puerto Rican Americans, and she wrote Talbot to thank him for it and offer her positive assessment. She also noted "that while it may be less important, it has surprised me however, that I have asked many Hispanic leaders and other people about that Father [Fitzpatrick] who wrote the book, and many do not know him." 85

85 Carmen Canales to John F. Talbot, S.J., April 15, 1974, Fitzpatrick Papers, Box 9, File 19. 